Article

\title{
Going Intellectually Green: Exploring the Nexus between Green Intellectual Capital, Environmental Responsibility, and Environmental Concern towards Environmental Performance
}

\author{
Syed Mir Muhammad Shah ${ }^{1}$, Umair Ahmed ${ }^{2, *(\mathbb{D}}$, Abdussalaam Iyanda Ismail ${ }^{3}$ and Soleman Mozammel ${ }^{2}$ \\ 1 Department of Business Administration, Sukkur IBA University, Sukkur 65200, Pakistan; \\ syedmir@iba-suk.edu.pk \\ 2 Business Studies Department, Arab Open University, Aali 973, Bahrain; soleman.mozammel@aou.org.bh \\ 3 Business Administration Department, University of Fujairah, Fujairah P.O. Box 1207, United Arab Emirates; \\ iyanda@uof.ac.ae \\ * Correspondence: umair.ahmed@aou.org.bh
}

\section{check for} updates

Citation: Shah, S.M.M.; Ahmed, U.; Ismail, A.I.; Mozammel, S. Going Intellectually Green: Exploring the Nexus between Green Intellectual Capital, Environmental

Responsibility, and Environmental Concern towards Environmental Performance. Sustainability 2021, 13, 6257. https://doi.org/10.3390/ su13116257

Academic Editor: Anna Mazzi

Received: 28 March 2021

Accepted: 5 May 2021

Published: 1 June 2021

Publisher's Note: MDPI stays neutral with regard to jurisdictional claims in published maps and institutional affiliations.

Copyright: (c) 2021 by the authors. Licensee MDPI, Basel, Switzerland. This article is an open access article distributed under the terms and conditions of the Creative Commons Attribution (CC BY) license (https:// creativecommons.org/licenses/by/ $4.0 /)$.

\begin{abstract}
In the workplace, green prospects are gaining much importance these days, although not much is known about the green intellectual capital and its contribution towards pro-environment behavior and outcomes. As the world experiences environmental concerns, it has become imperative for businesses to look into ways through which they can improve their environmental footprints. Hence, the current study examines the nexus between green intellectual capital (green human capital, green structural capital, and green relational capital) and environmental performance. The study also tested if environmental responsibility mediates the association and examined the role of environmental concern as a moderator. Data were gathered from the hotel sectors in Bahrain and the United Arab Emirates and analyzed using a structural equation modeling approach via Smart PLS. The results show a significant association between green human and relational capital with environmental performance; a strong association was also found between environmental responsibility and environmental performance. The results also report a significant association between the three factors of green intellectual capital and environmental responsibility. The results found a mediating effect of environmental responsibility, whereas environmental concern only moderated the association between green human capital and environmental performance. The study presents prominent implications for theory and practice, followed by recommendations for future studies.
\end{abstract}

Keywords: green intellectual capital; environmental performance; environmental concern; environmental responsibility

\section{Introduction}

Globally, environment conservation recieves much attention, resulting in business entities putting time, effort, and investments towards promoting environmentally friendly behaviors at the workplace [1]. Parallel to other industries, e.g., [2,3], the hotel sector has also been noticed to be taking on substantial "green" initiatives and practices $[4,5]$. In this regard, many prior studies have empirically proven that deploying operational policies can efficiently help boost pro-environment behaviors and outcomes.

However, the majority of organizations still seem to be unsure of what strategies to use [6], hence there is a constant search for new and innovative approaches to lessen the deleterious impact of individual and organizational activities on the environment. Interestingly, [7] asserted that efforts towards harnessing the intellectual capital of a business focused towards protecting the environment (Green Intellectual Capital-GIC) can be instrumental in facilitating the achievement of strategic goals and objectives. Green intellectual capital comprises internal intangible capabilities that can help a business boost its operational efficiency to further its outcomes. Intellectual capital is a summation of all 
intangible resources of a business that are, at times, even more important than the tangible ones [8]. Studies have reported the vitality of intellectual capital towards organizational performance outcomes, e.g., [9,10]. However, less is known about GIC in both the academic and practitioner worlds [6]. More importantly, in the hotel industry, there appears to be a scarcity of research outlining how such an important sector, in which many economies like the United Arab Emirates and Bahrain thrive, can make the most out of boosting its pro-environment behaviors and outcomes. Chen [7] appears to be the pioneer of the GIC concept, which is defined as the "sum of all knowledge that an organization is able to leverage in the process of conducting environmental management" (p. 21). The three main components that form GIC are named as "green human capital" (GHC), "green structural capital" (GSC), and "green relational capital" (GRC).

The significance of the current study is multifaceted. The aim of the study was to respond to major empirical and practitioner gaps, as green intellectual capital has yet to be investigated in the hospitality sector. Secondly, Bahrain and the United Arab Emirates are some of the region's best countries for tourism [11], and so much of these economies rely on tourists and the money they spend during their stay. The tourism sector, on which the hotel sector thrives, contributed to 7\% of the GDP of Bahrain in 2017 and is set to reach $11 \%$ by 2028 [12]. Accordingly, the contribution of the tourism sector in the United Arab Emirates is $12.1 \%$ of the GDP, which is set to go up to $12.4 \%$ by 2027, as per the United Arab Emirates Information Services Portal. Hence, providing empirical results for the hotel sector to help improve their pro-environmental footprint is critical. Moreover, Umrani et al. [4] has asserted the need for investigating green prospects in the hotel sector. Equally, similar assertions have been hinted at by Nimri et al. [13] in their investigation into the hotel sector in Australia. Overall, the conceptualized model of the current study is novel since a lack of prior studies is evident in the literature on GIC and environmental performance relations. Accordingly, to what amount GIC contributes to environmental responsibility and environmental concern is another notable scholarly area the present study contributes to. In addition, whether environmental responsibility can intervene or not, the association between GIC and environmental performance presents another interesting gap that the current study addresses. Following this, the present study sheds empirical light on how environmental concern may translate into furthering the direct associations between green intellectual capital, environmental responsibility, and environmental performance. Furthermore, the particular focus on the hotel sector, on which there appears to be an absolute dearth of research about these associations, is another novel contribution of the current study.

The study poses the following research questions. RQ1: What is the influence of green intellectual capital on environmental performance? RQ2: Can environmental responsibility mediate the association between the three factors of green intellectual capital and environmental performance? RQ3: What is the moderating effect of environmental concern on the nexus between green intellectual capital, environmental responsibility, and environmental performance?

\section{Literature Review}

In a constantly changing environment, the world has changed its focus more towards intangible assets as opposed to previously tangible assets, with a belief that it can achieve better performance [14,15]. According to Obeng et al. [16], intangible assets ensure the survival of organizations. They also encourage the creation of value [17] as well as enhancing competitive advantages over those offered by tangible assets [18]. According to Alcaniz et al. [19], intangible assets are referred to as the intellectual capital (IC) of an organization. Ahmed and Ahmed [20] stated that organizations with higher IC enjoy more benefits over organizations with poor IC. At the same time, Verbano and Crema [21] posited IC as a strong defense against any weakness that SMEs may face.

According to Bontis [22], John Kenneth Galbraith devised the term 'IC' in 1969. The term was further popularized as a concept in 1991 by Tom Stewart [23]. Since then, the 
concept of intellectual capital has engendered a series of discussions in vast literature through numerous disciplines. According to Marr and Moustaghfir [24] IC is defined as the summation of knowledge in businesses that confirms competitive advantages in the marketplace or the total frameworks of the collective knowledge on information, technologies, intellectual property rights, experience, organizational learning and competence, team communication systems, customer relations, and brands, which generate significant value for organizations. Roos and Roos [25] stated that IC caters to non-financial and intangible resources that are typically coordinated by the management of an organization aiming to create organizational value. Another contributor to the term, Bontis et al. [26] portrayed IC as a term specified to all intangible assets that empower organizations to operate with a purpose. According to Choong [27], employees possess IC with their set of knowledge, whereas organizations accomplish competitive benefits by utilizing it effectively to construct wealth.

Most definitions of Intangible Capital carry similar meanings in numerous literature of the IC concept. The definitions discussed above may be drawn on IC being a description of all intangible capitals enabling organizations to create and sustain value, resulting in accomplishing competitive advantage. At the same time, the literature of IC concepts has been illustrated further by scholars from innumerable viewpoints. Nevertheless, green intellectual capital (GIC), which is an assimilation of both IC and with environmental concepts, remains quite unusual among both scholars and practitioners due to not giving reasonable attention. The concept of GIC was first coined by Chen [7]. Following this, the GIC concept was posited by Yong et al. [3]. Out of these handful of definitions, GIC is described as the combination of intangible subjects such as, resources, capabilities, knowledge, and their relationships for green protection or environmental improvement. GIC is also described as the sum of capability and green knowledge of organizations to improve competitive advantages [28]. According to Chen [29], environmentalism as a concept has become widely acceptable in the current business practice, aiming to cut back environmental effects and regulate climate transformations to increase motivation among organizations to be more productive towards green improvement.

Nevertheless, the trend of consumers becoming more informed on various environmental issues is resulting in pushing businesses to adopt proactive approaches to conform with current trends of environmental management for a sustainable competitive position [30]. Similar has also been echoed by other authors asserting that organizations complying with strict international environmental regulations are resulting in meeting growing consumer demands regarding environmental sustainability through Green Intellectual Capital [31]. In order to adopt an environmental approach effectively, an organization must demonstrate sufficient environmental understanding that may assist them in establishing essential opportunities for revising work procedures and product modification [7]. Therefore, GIC concept minimalizes environmental effect and stipulates the desired competitive advantages to organizations resulting in cost savings. There are three main components, suggested by Chen [7], which include green human capital (GHC), green structural capital (GSC) and green relational capital (GRC). Limited scholarly attention can be traced regarding green intellectual capital. Within the limited literature, it is evident that green intellectual capital components have a progressive impact on organizational outcomes $[3,6]$. According to Aboelmaged and Hashem [32], green innovation adaption is significantly affected by sustainable human capital. Accordingly, organizational learning capability also positively relates to business sustainability [6]. In parallel, green intellectual capital is also found promising financial performance outcomes [33]. Notably, green intellectual capital is also termed instrumental for environmental consciousness and competitive benefits [7,31].

\section{Hypotheses Development}

3.1. Green Human Capital and Environmental Performance

Wright et al. [34] posited human capital as some of the notable prospects for businesses to gain competitive advantage. Scholars have suggested human capital to be one 
of the primary strategic resources behind organizational success as employees play an important role in sustaining business in the current rapidly changing business environment [35]. Additionally, Davidsson and Honig [36] stated that higher knowledge and skills of employees enhance productivity. Based on these assertions, it can be argued that the knowledge-based era demands organizations to acquire knowledgeable employees, decision makers, and problem solvers. Accordingly, it continuous development of skills and knowledge-savvy behaviors of employees is much needed in the current era, resulting in enhanced work efficiency, reduced errors in decision-making, enhanced work quality, and higher performance [37].

Notably, organizations today also consider environmental aspects, thus resulting in the exploration of the role of GHC towards business sustainability According to Yong et al. [3], some evidence confirms the positive effect of GHC on GHRM. At the same time, Chang and Chen [38] also provided confirmation to the link between GHC and green innovation performance. Nonetheless, empirical evidence on green human capital is limited [3]. Luckily, some recent evidences provide scholarly insight on this. For example, study conducted in the Malaysian manufacturing sector confirmed the significant role of green intellectual capital in harnessing environmental performance [39]. Hence, the authors argue that green human capital can facilitate an organization to identify, embrace and appreciate its intangible resources for responsive formation and implementation of green strategies to boost environmental performance. Thus, we test:

Hypothesis 1 (H1). There is a positive relationship between green human capital and environmental performance.

\subsection{Green Structural Capital and Environmental Performance}

Prominent work in the domain has outlined structural capital as knowledge catering to non-human prospects of a business. Therein, Chen [7] has defined green structural capital "as tangible assets and evident prospects that outline environmental concern or green developments in the business which includes organizational capabilities, reward systems, organizational culture, databases, knowledge management systems, information technology and so on" (p. 227). It is important to note that green human capital alone cannot effectively generate promising pro-environment results, particularly in the absence of required organizational structure, information systems, and strategies needed in this regard [40]. This is since organizations cannot achieve satisfactory performance if they possess poor systems and procedures [41]. Furthermore, organizations that possess strong structural capitals enjoy an encouraging environment that enhances employee motivation to continuous knowledge acquisition [42], hence strengthening organizational capabilities. Furthermore, organizations must also aim to develop a constant pro-environmental structure and organizational capabilities to respond to climate calls. This may include the development of responsive organizational procedures [43], and proper research and development [44]. Accordingly, green culture [3] and information technology such as electronic HRM [45] were also found boosting green outcomes. Notably, green structural capital is also termed significant in boosting organization's competitive position [46]. Similarly, scholars in the past have also recognized the significance of structural capital in improving performance-based outcomes [39,47]. Notably, pertaining to environmental performance, green structural capital is also reported promising [31]. Therefore, the authors speculate that the green structural capital will facilitate the organization to implement pro-environment behaviors resulting in boosting environmental performance; association that has received limited empirical attention. Hence, we test:

Hypothesis 2 (H2). There is a positive relationship between green structural capital and environmental performance. 


\subsection{Green Relational Capital and Environmental Performance}

Relational capital (RC) empowers information sharing between partners. According to Chen [7], green relational capital denotes to "intangible assets of the company that are based on the relationship between organization, supplier, customers, green innovation network members and partners about corporate environmental management with the aim to obtain competitive advantages" (p. 278). Every organization strives for information acquisition from its stakeholders by establishing greater communication between partners and achieves enhanced organizational outcomes. Doz [48] echoes the same, stating that partners establish a relationship through collaboration between expectations resulting in improving and stimulating learning. As a result of these well-bonded relationships, organizations enjoy greater performance and goal achievement [49]. Notably, businesses engaged in the manufacturing sector are showcasing them leaning towards building close relationships for promising materialistic [50] and environmental goals [44]. Importantly, Dickel et al. [51] asserted that green collaborations also help spread environmental awareness among partners that can translate into harnessing better environmentally friendly behaviors.

Furthermore, green association between partners, including entities in the supply chain [52] and with customers [53] has gained much appreciation in recent years as it can help boost both environmental responsibility as well as the pro-environment performance of the business. Hence, the authors potentially speculate that green relational capital will influence environmental performance. Therefore, we posit:

Hypothesis 3 (H3). There is a positive relationship between green relational capital and environmental performance.

\subsection{Environmental Responsibility and Environmental Performance}

Pro-environment researchers define environmental responsibility as a sense of obligation catering to outlining right and wrong based on moral values [54]. Typically, what has been observed in some studies, e.g., [55], is that that socially vigilant businesses and their workforce showcase environmental responsibility through taking measures to curb deleterious effects of the business activities on the environment. In connection with environmental performance, research suggests that environmental responsibility foster a culture of working on pro-environment activities and avoiding entities that may contribute to environmental degradation, thus boosting environmental performance [56]. Environmental responsibility emboldens organizations to rethink on their current and forthcoming actions [54]. Hence, we posit the following:

Hypothesis 4 (H4). There is a positive association between environmental responsibility and environmental performance.

\subsection{Green Human Capital and Environmental Responsibility}

Similar to the role of green intellectual capital towards harnessing environmental performance, we assert that it will also influence the sense of environmental responsibility. We present come arguments in this regard. For example, human capital serves as the strategic source to help provide knowledge to organizations and their employees to sustain [35], whereby, organizations have been found making responsive developments in their pro-environment activities through knowledge savvy behaviors to overcome deleterious effects of organizational activities towards the environment [39], thus building environmental responsiveness. Based on these arguments, we assert that green human capital will enlighten businesses to be socially vigilant organizations and their employees to understand how different business activities are affecting the environment thereby taking effectives measures, thus predicting environmental responsibility; a relationship that to the best of authors' knowledge is yet to be investigated. 
Hypothesis 5 (H5). There is a positive relationship between green human capital and environmental responsibility.

\subsection{Green Structural Capital and Environmental Responsibility}

Typically, knowledge catering to non-human prospects of the business is referred as structural capital. A business having a robust structural capital will support green prospects, enabling the organization and its employees to learn new skills and proactively strive to understand how things could be responsively done [6]. Thus, green structural capital in the shape of information systems, policies, and strategies [40] helps to utilize human capital to build skills and capabilities to respond to climate calls. In a nutshell, green structural capital provides a platform for the acquisition of pro-environment knowledge, the ability to understand the promises and perils of organizational activities towards the environment, and clarifying to work on improving them [31]. Therefore, in light of these arguments, we assert that green structural capital will facilitate the mechanism of understanding the effects of different organizational activities and thereby providing supportive systems, policies, and infrastructure to minimize it, hence predicting environmental responsibility-a link which is yet to receive empirical attention.

Hypothesis 6 (H6). There is a positive relationship between green structural capital and environmental responsibility.

\subsection{Green Relational Capital and Environmental Responsibility}

As relational capital (RC) empowers information sharing between partners, we assert that the green relational capital catering to intangible assets of the business on the grounds of its relationship with suppliers, customers, green innovation members, and pro-environment associations can significantly help boost environmental responsibility. Doz [48] highlights that partners establish a relationship through collaboration between them to improve and stimulate learning which helps them have a responsive organizational functioning [49]. Similarly, green associations between partners, including entities in the supply chain [52] and with customers [53] has helped boost pro-environment behaviors, making organizations and their people concerned about how business activities are affecting and can be improved to make the environment more sustainable. Hence, the authors see it as logical to test the green relational capital and environmental responsibility link, thus addressing a major research gap.

Hypothesis 7 (H7). There is a positive association between green relational capital and environmental responsibility.

\subsection{Mediation of Environmental Environmental Responsibility}

According to Aarnio-Linnanvuori [54], environmental researchers viewed environmental responsibility as an ethical prospect catering to the right, the wrong, and the liability elements. Middlemiss [57] has outlined environmental responsibilities as duties that people are individually connected with, making them emotionally charged, if not attained. According to Aarnio-Linnanvuori [54], environmental responsibility is concerned with looking back into the activities and systems when harmful actions seem to cause an effect on the environment. As per Fahlquist [58] has stated that environmental responsibility has a more focus on the future course of actions. Therefore, it is observed from literature that employees who practice GHRM pay attention to environmental issues by learning about environmental management systems and acquiring environment protection skills [59]. Scholars have outlined the significance of employees' pro-environment responsiveness in managing the environmental damage by an organization, thus improving environmental performance [60]. Similar empirical evidence was also forwarded by Reilly [61] and Stanwick and Stanwick [62], outlining the instrumental role of environmental responsibility for 
pro-environment performance. Hence, the promising role of environmental responsibility towards harnessing environmental performance can be seen logical.

Talking about the mediation, a recent study by Umrani et al. [4] tested and found significant mediation of environmental responsibility in the relationship between green HRM and environmental performance. Hence, it confirms that pro-environment prospects in the organizations induce environmental responsibility, which later predicts green performance. Therefore, the study speculates that green intellectual capital factors will provoke green work behaviors among employees by making them responsible, thus contributing to environmental performance. Hence, we test:

Hypothesis 8 (H8). Environmental responsibility mediates the association between green human capital and environmental performance.

Hypothesis 9 (H9). Environmental responsibility mediates the association between green structural capital and environmental performance.

Hypothesis 10 (H10). Environmental responsibility mediates the association between green relational capital and environmental performance.

\subsection{Moderation of Environmental Concerns}

According to Turker [63], employees with a positive social responsibility perception demonstrate commitment to their organization. Yen, Chen, and Teng [64] echoed the same by arguing that employees demonstrating positive ambitions towards environmental management activities are also susceptible to predicting organizational commitment. Literature suggests environmental concern can be seen as an important pro-environmental behavior [65]. According to Kim et al. [66], an organization's environmental performance is impacted by various pro-environment practices. Hence, the authors of the current study speculate that employees' environmental concerns can potentially become instrumental for environmentally friendly outcomes. According to Han et al. [65], research provides evidence that individuals with deep concerns about environmental problems and knowledge of dealing with them demonstrate environmentally responsible behavior, resulting in organizations accomplishing environmental performance. Therefore, the authors believe that the relationship between green intellectual capital and environmental performance will be robust when employees showcase consciousness towards the environment. Hence, we test:

Hypothesis 11 (H11). Environmental concerns moderates the association between green human capital and environmental performance.

Hypothesis 12 (H12). Environmental concerns moderates the association between green structural capital and environmental performance.

Hypothesis 13 (H13). Environmental concerns moderates the association between green relational capital and environmental performance.

Hypothesis 14 (H14). Environmental concerns moderates the association between environmental responsibility and environmental performance.

\section{Research Methodology}

\subsection{Survey and Data Collection Procedure}

To test the hypotheses of the present study, we used a cross-sectional survey implemented in two countries: Bahrain and United Arab Emirates (UAE). The study adopted convenience sampling technique. The study sample comprised employees of the hotel industry. Data were collected from November 2020 through January 2021 via in-person visits and online questionnaire distribution. The survey instruments were developed to analyze the conceptual model, evaluate the relationships. Measurement scales were designed from 
the previous literature. However, few adjustments were made in the wording of the items to fit the context of the study. The constructs of the study include green intellectual capital, green structural capital, green relational capital, environmental responsibility, environmental concerns, and environmental performance. All items measuring these constructs are further discussed in this section. The study unit of analysis was employees of hotel organizations in Bahrain and UAE. The hotel organizations were used in this study due to their exposure to environmental challenges and their subjectivity to external forces such as government policies. The works of Guerci, Longoni, and Luzzini [67], Amran, Ooi, Nejati, Zulkafli, and Lim [68], and Tzafrir [69] affirm these requirements. The researchers distributed 500 employee-supervisor matched questionnaires in both countries and received 386 completed responses. However, out of these 382, only 346 questionnaires were appropriately filled and used for this study representing a $69 \%$ acceptable and significant response rate.

\subsection{Constructs' Measures}

The research employed measurement items from previous literature. The dimensions employed to measure green intellectual capital were green human capital, green structural capital, and green relational capital. All of these were adapted from Chen [7]. Accordingly, environmental performance items were adopted from Paillé et al. [70] and Melnyk et al. [71]. The questionnaire was ranked/scaled on a five-point Likert scale varying from " 1 " meaning "strongly disagree" to " 5 " meaning "strongly agree". References for all the measurement instruments are provided in Table 1.

Table 1. Constructs/measurement sources.

\begin{tabular}{cccc}
\hline Variable & Dimensions & No. of Items & Source \\
\hline Green intellectual capital & Green human capital & 5 & Chen [7] \\
& Green structural capital & 4 & Chen [7] \\
& Green relational capital & 4 & Chen [7] \\
Environmental performance & - & 5 & Paillé et al. [70] and Melnyk [71] \\
Environmental responsibility & - & 4 & Turker [72] \\
Environmental concern & - & 4 & Malik et al. [73] \\
\hline
\end{tabular}

\subsection{Data Analysis Procedure}

This study employed the SmartPLS 3.3.3 software suite [74]. PLS-SEM involves multistage assessment: first, evaluation of the measurement model and second, evaluation of the structural model $[75,76]$. The prerequisite of the measurement model ensures that only the constructs that have strong indicator loadings, convergent validity, Cronbach alpha (CA), composite reliability (CR), and discriminant validity should be employed in the structural model. While the evaluation of the structural model is intended to determine the path coefficients of all indicators and measure their significance through bootstrapping process. Regarding mediation evaluation, Preacher and Hayes [77] procedure was adopted as it is the more rigorous method of assessing mediating effects and more appropriate for use with the PLS-SEM method $[78,79]$. Most recent GIC analysis studies have used the PLS-SEM data evaluation method to analyze data $[31,38,66,80]$.

\subsection{Common Method Bias (CMB)}

Harman's single factor test was performed to assess the common method bias problem (CMB). According to Podsakoff, MacKenzie, and Lee [81], owing to the evaluation of the exogenous (independent) and endogenous (dependent) by the same participant at the same time, the self-reported study may appear to be of a CMB concern [82,83]. According to Herman's single-factor method, the total variance value must be below $50 \%$. The total variance value in this present study was $36.40 \%$. Thus, the sample data in this study have no common method bias. 


\subsection{Demographic Profile of Respondents}

Out of the 346 respondents, 194 were male, and 152 reported as female. In terms of years of experience, 82 reported 15 to 20 years of experience, 136 reported having 5 to 10 years of experience in the industry, whereby the remaining 128 mentioned having less than 5 years of experience in the hotel industry. In connection to qualification, 110 reported having a master's degree or postgraduate diploma, 155 as having an undergraduate degree while 81 as high school diploma holders.

\subsection{Measurement Model Assessment}

The first-phase assessment of the measurement model was carried out to validate the reliability and validity of the constructs and their loadings [79]. Factor loadings, Cronbach alpha (CA), composite reliability (CR), average variance extracted (AVE) were all employed to evaluate the convergent validity followed by the discriminant validity [84]. While assessing the measurement model, no items were omitted since all their factor loadings were above the threshold value of 0.60 . Hence, all the measurement items were included in the measurement model. Table 2 and Figure 1 show that all the factor loadings are higher than the recommended threshold of 0.6. Similarly, the CA, CR, and AVE are all above the recommended value of $0.70,0.70$, and 0.50 , respectively. Therefore, convergent validity and reliability were defined. To further check for the robustness of the measurement model, we assess the discriminant validity (see Table 3) through the Heterotrait-Monotrait (HTMT) Ratio [84].

Table 2. Item loadings, reliability, internal consistency and convergent validity.

\begin{tabular}{|c|c|c|c|c|}
\hline Variables & Loadings & CA & CR & AVE \\
\hline \multicolumn{5}{|l|}{ Green human capital } \\
\hline Green intellectual capital & & 0.764 & 0.841 & 0.515 \\
\hline GHC1 & 0.752 & & & \\
\hline GHC2 & 0.778 & & & \\
\hline GHC3 & 0.688 & & & \\
\hline GHC4 & 0.698 & & & \\
\hline GHC5 & 0.666 & & & \\
\hline Green structural capital & & 0.854 & 0.902 & 0.699 \\
\hline GSC1 & 0.756 & & & \\
\hline GSC2 & 0.898 & & & \\
\hline GSC3 & 0.766 & & & \\
\hline GSC4 & 0.911 & & & \\
\hline Green relational capital & & 0.869 & 0.911 & 0.72 \\
\hline GRC1 & 0.762 & & & \\
\hline GRC2 & 0.913 & & & \\
\hline GRC3 & 0.821 & & & \\
\hline GRC4 & 0.891 & & & \\
\hline Environmental performance & & 0.848 & 0.891 & 0.622 \\
\hline $\mathrm{EP} 1$ & 0.860 & & & \\
\hline EP2 & 0.874 & & & \\
\hline EP3 & 0.781 & & & \\
\hline EP4 & 0.664 & & & \\
\hline EP5 & 0.746 & & & \\
\hline \multicolumn{5}{|l|}{ Environmental responsibility } \\
\hline ER1 & 0.826 & 0.851 & 0.9 & 0.692 \\
\hline ER2 & 0.790 & & & \\
\hline ER3 & 0.839 & & & \\
\hline ER4 & 0.872 & & & \\
\hline \multicolumn{5}{|l|}{ Environmental concern } \\
\hline $\mathrm{EC} 1$ & 0.631 & 0.799 & 0.866 & 0.621 \\
\hline EC2 & 0.765 & & & \\
\hline EC3 & 0.856 & & & \\
\hline EC4 & 0.877 & & & \\
\hline
\end{tabular}




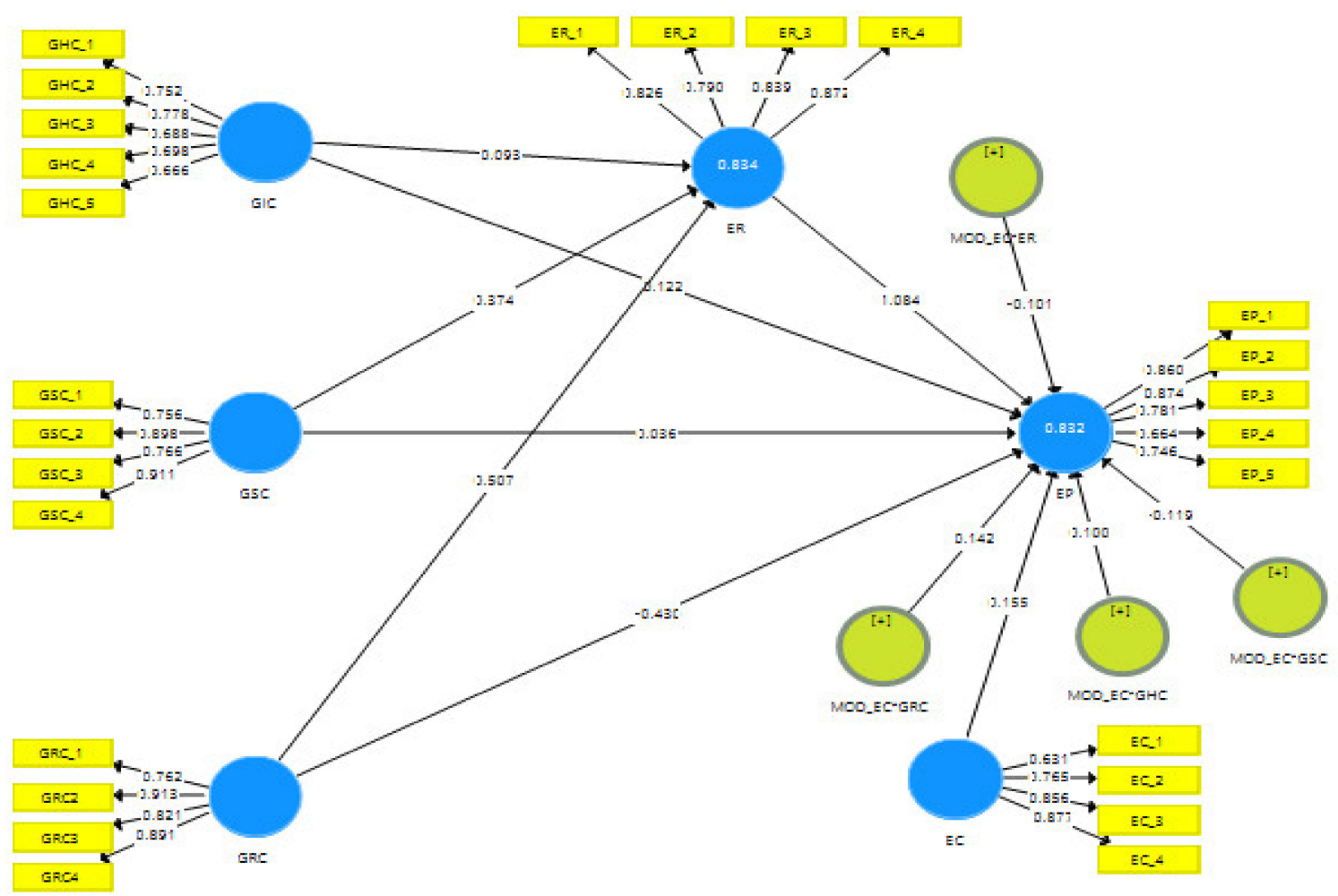

Figure 1. Measurement Model.

Table 3. Discriminant validity (HTMT criterion).

\begin{tabular}{ccccccc}
\hline Constructs & EC & EP & ER & GIC & GRC & GSC \\
\hline EC & & & & & & \\
EP & 0.517 & & & & \\
ER & 0.400 & 0.783 & & & \\
GHC & 0.728 & 0.647 & 0.564 & & \\
GRC & 0.403 & 0.789 & 0.341 & 0.524 & & \\
GSC & 0.380 & 0.813 & 0.208 & 0.514 & 0.138 & \\
\hline
\end{tabular}

Note: EC: environmental concern; EP: environmental performance: ER: environmental responsibility; GHC: green human capital; GRC: green relational capital; GSC: green social responsibility.

\subsection{Structural Model Assessment}

To assess the structural model, Hair et al. [84] proposed looking at the $\mathrm{R}^{2}$ value, beta values and the corresponding t-values through a bootstrapping process with a resample of 5000 [74]. The results show $R^{2}$ values of 0.832 and 0.834 for environmental performance and environmental responsibility, respectively. The $\mathrm{R}^{2}$ values confirm the predictive capacity of the model [85] since they are above the required level of 0.10 [86]. In addition, the Stone-Geisser $\left(\mathrm{Q}^{2}\right)$ test was done to assess the predictive relevance. This test can be done in conjunction with the $R^{2}$ values (predictive accuracy) as an additional assessment of the model fit in PLS analysis [87,88]. As stated by Chin [89], $\mathrm{Q}^{2}$ is the test of how well observed values are replicated by the model and the parameters it estimates. In SmartPLS 3.3.3, the $\mathrm{Q}^{2}$ is computed by using the blindfolding method. $A \mathrm{Q}^{2}$ value greater than zero (0) are considered to have a predictive relevance, as suggested by Chin [89]. A $Q^{2}$ value greater than $0.35,0.15$ and 0.02 indicates large, medium, and small predictive relevance, respectively, as recommended by Cohen et al. [90]. All $Q^{2}$ values for the endogenous constructs (e.g., $\mathrm{EP}=0.493$ and $\mathrm{ER}=0.563$ ) are greater than zero (see Table 4 ) and are large in predictive relevance. Therefore, this supports the validity of the model as regards to endogenous latent variables. 
Table 4. Results of structural model path coefficient (direct relationships).

\begin{tabular}{|c|c|c|c|c|c|c|c|}
\hline Hypotheses & Relationship & $\beta$ & SD & $t$-Value & $p$-Values & BI $(2.5 \% ; 97.5)$ & Decision \\
\hline $\mathrm{H} 1$ & $\mathrm{GHC} \rightarrow \mathrm{EP}$ & 0.122 & 0.035 & 3.489 & 0.001 & $(0.043 ; 0.189$ & Supported \\
\hline $\mathrm{H} 2$ & $\mathrm{GSC} \rightarrow \mathrm{EP}$ & 0.036 & 0.115 & 0.315 & 0.753 & $(-0.196 ; 0.282)$ & Not supported \\
\hline H3 & $\mathrm{GRC} \rightarrow \mathrm{EP}$ & 0.430 & 0.120 & 3.589 & 0.000 & $(0.643 ; 0.183)$ & Supported \\
\hline $\mathrm{H} 4$ & $\mathrm{ER} \rightarrow \mathrm{EP}$ & 1.084 & 0.069 & 15.658 & 0.000 & $(0.906 ; 1.219)$ & Supported \\
\hline H5 & $\mathrm{GHC} \rightarrow \mathrm{ER}$ & 0.093 & 0.037 & 2.501 & 0.013 & $(0.03 ; 0.155)$ & Supported \\
\hline H6 & $\mathrm{GSC} \rightarrow \mathrm{ER}$ & 0.374 & 0.103 & 3.622 & 0.000 & $(0.126 ; 0.590)$ & Supported \\
\hline $\mathrm{H} 7$ & $\mathrm{GRC} \rightarrow \mathrm{ER}$ & 0.507 & 0.101 & 5.028 & 0.000 & $(0.300 ; 0.717)$ & Supported \\
\hline $\mathrm{EP}$ & $\mathrm{R}^{2}=0.832$ & $\mathrm{Q}^{2}=0.493$ & & & & & \\
\hline ER & $\mathrm{R}^{2}=0.834$ & $\mathrm{Q}^{2}=0.563$ & & & & & \\
\hline \multicolumn{8}{|c|}{ Effect size of the exogenous variables on endogenous variable(s) } \\
\hline & & & & & $\mathrm{GHC} \rightarrow \mathrm{EP}$ & $f^{2}=0.049$ & Small \\
\hline & & & & & $\mathrm{GSC} \rightarrow \mathrm{EP}$ & $f^{2}=0.001$ & None \\
\hline & & & & & $\mathrm{GRC} \rightarrow \mathrm{EP}$ & $f^{2}=0.067$ & Small \\
\hline & & & & & $\mathrm{EC} \rightarrow \mathrm{EP}$ & $f^{2}=0.085$ & Small \\
\hline & & & & & $\mathrm{ER} \rightarrow \mathrm{EP}$ & $f^{2}=1.009$ & Large \\
\hline & & & & & $\mathrm{GHC} \rightarrow \mathrm{ER}$ & $f^{2}=0.043$ & Small \\
\hline & & & & & $\mathrm{GSC} \rightarrow \mathrm{ER}$ & $f^{2}=0.077$ & Small \\
\hline & & & & & $\mathrm{GRC} \rightarrow \mathrm{ER}$ & $f^{2}=0.140$ & Medium \\
\hline
\end{tabular}

Notes: GHC: means green human capital; GSC: means green structural capital; GRC: means green relational capital; EP: means environmental performance; ER: means environmental responsibility; $\beta$ : is the path coefficients: SD: means standard deviation; BI: means confidence interval bias-corrected; $R$ squared: is the variance explained in the endogenous variables by the exogenous variables; $Q$ squared: is the predictive relevance; $f$ squared: is the effect size.

Finally, the effect sizes $\left(f^{2}\right)$ are assessed in order to determine the degree to which the predictive (exogenous) variables contribute to the endogenous variable(s) $R^{2}$ value and the predicted relevance as suggested by Henseler et al. [91]. The values of $\left(f^{2}\right)$ greater than $0.02,0.15$, and 0.35 are considered small, medium, and large effect sizes, as suggested by Cohen [90]. In this study, the ER was predicted by GHC, GSC, and GRC with small, small, and medium effect sizes. EP was also predicted by GHC, GSC, GRC, EC and ER with, small, none, small, small and large effect sizes, respectively (see Table 4) for the values. See Table 4 for the comprehensive details of the structural model assessment.

In the second phase of the analysis, the assessment of the structural model test was carried out. The hypotheses were evaluated in sequence. First, it analyzed the direct influence of GHC, GSC, GRC, and EC on EP. Second, the indirect effect of ER on GHC, GSC, GRC and EP were examined. Lastly, the moderating effect of EC was tested on the exogenous variables (GHC, GSC, GRC, ER) and the endogenous variable (EP). To establish the significance of direct paths, the bootstrap resampling method was used with 5,000 resamples [74]. The test results of hypotheses designed for direct relationship are described in Table 4. The effect of GHC, GSC, and GRC on EP was checked through the intervention of ER. Table 5 shows the effects of the examination of mediation. Finally, the moderating role of EC on the relationship between GHC, GSC, GRC, and ER on EP was also examined. See Table 5 for the comprehensive details of moderating effect.

Table 5. Mediation analysis (indirect effects).

\begin{tabular}{|c|c|c|c|c|c|c|}
\hline & Indirect Effect & & & & & \\
\hline & Hypotheses & $\beta$ & SD & $t$-value & $p$-value & Decision \\
\hline H8: & $\mathrm{GHC} \rightarrow \mathrm{ER} \rightarrow \mathrm{EP}$ & 0.101 & 0.039 & 2.604 & 0.010 & Complementary mediation \\
\hline H9: & $\mathrm{GSC} \rightarrow \mathrm{ER} \rightarrow \mathrm{EP}$ & 0.405 & 0.140 & 2.900 & 0.004 & Full mediation \\
\hline H10: & $\mathrm{GRC} \rightarrow \mathrm{ER} \rightarrow \mathrm{EP}$ & 0.549 & 0.113 & 4.840 & 0.000 & Competitive mediation \\
\hline
\end{tabular}


The results revealed a substantial positive effect of GHC on EP $(\beta=0.122, t=3.273$, $p<0.005)$. Hence, $\mathrm{H} 1$ was supported. Similarly, there is insignificant direct influence of GSC on EP ( $\beta=0.036, t=0.315, p=0.753)$. Therefore, $\mathrm{H} 2$ was rejected. Moreover, GRC impact on EP was found to be negatively significant $(\beta=-0.430, t=3.589, p<0.005)$. Hence, $\mathrm{H} 3$ was supported. The results also recognize the positive significant effect of ER on EP ( $\beta=1.084, t=15.658, p<0.005)$. Therefore, $\mathrm{H} 4$ was accepted. The direct influence of GHC on ER was also tested, and it was found that there is a positive and significant influence of GHC on ER ( $\beta=0.093, t=2.501, p<0.005)$. Thus, H5 was supported. Furthermore, the direct influence of GSC on ER was also examined. It was found that GSC influence ER positively and significantly $(\beta=0.374, t=3.622, p<0.005)$. Therefore, $\mathrm{H} 6$ was accepted. Lastly, the findings also revealed a substantial effect of GRC on ER ( $\beta=0.507, t=5.028$, $p<0.005)$. Therefore, H7 was accepted.

\section{Mediation Analysis}

Table 5 contains the information about the mediating role of environmental responsibility. The relationship between GHC and EP is somewhat strong (0.122) and statistically significant $(t=3.489 ; p<0.001)$. The indirect effect $(\mathrm{GHC} \rightarrow \mathrm{ER} \rightarrow \mathrm{EP})(\beta=0.101 ; t=2.604$; $p<0.05)$ is significant, and the $95 \%$ confidence intervals does not include zero. Thus, it could be asserted that ER complementarily and/or partially mediates the GHC-EP relationship. To further substantiate the mediation testing, the product of the direct effect and the indirect effect was computed (i.e., $0.122 * 0.101=0.012$ ). Hence, ER represents complementary mediation of the relationship from GHC to EP. This indicates the best-case scenario as this finding suggests that ER fully complies with the hypothesized theoretical framework [84].

The relationship between GSC and EP is statistically non-significant $(\beta=0.036$; $t=0.315 ; p>0.05)$, but the indirect effect (GSC $\rightarrow \mathrm{ER} \rightarrow \mathrm{EP})[\beta=0.405 ; t=2.900 ; p<0.05]$ is significant, and the $95 \%$ confidence intervals does not include zero. Thus, it could be asserted that ER fully mediates the GSC-EP relationship. To further substantiate the mediation testing, the product of the direct effect and the indirect effect was computed (i.e., $0.036 * 0.405=0.015)$. Hence, ER represents indirect-only mediation of the GSC-EP relationship. This indicates the best-case scenario as this finding suggests that ER fully complies with the hypothesized theoretical framework [84].

With regard to GRC $\rightarrow \mathrm{ER} \rightarrow \mathrm{EP}$ relationship, the direct path regarding relationship between GRC and EP (GRC $\rightarrow$ EP) is significant but negative $(\beta=-0.430 ; t=3.589$; $p<0.001)$. Nonetheless, the indirect effect (GRC $\rightarrow \mathrm{ER} \rightarrow \mathrm{EP}-\beta=0.549 ; t=4.840 ; p<0.001)$ is significant, and the $95 \%$ confidence intervals do not include zero. Thus, it can be asserted that ER competitively/partially mediates the relationship between GRC and EP. Hence, hypothesis 10 is supported. In this mediation model, ER represents an appropriate mechanism to explain the relationship between GRC and EP. Hence, the positive indirect effect via the mediator variable (ER) reveals the 'true' relationship between GRC and EP (Hair et al., 2017), because an estimated the cause-effect relationship between GRC and EP may not be the 'true' effect if ER (i.e., mediating variable or suppressor variable) is not accounted for in this research model.

\section{Moderation Analysis}

A few procedures were undertaken to examine the moderating role of environmental concern in the GHC-EP, GSC-EP, GRC-EP, ER-EP relationships. First, we investigate the interaction between GHC and EC. EP was regressed on GHC and EC (GHC*EC). The interaction terms were positive and significant $(\beta=0.100, t=3.375, p<0.005)$ and multicollinearity (VIF $=1.00$ ) was not a problem. Hence, environmental concern moderates the relationship between green human capital and environmental performance. Therefore, H11 was confirmed. The findings suggest that the positive relationship between green human capital and environmental performance is stronger in an organization that is characterized by high environmental concerns. A similar procedure was employed to establish the 
moderating role of EC on the relationship between GSC and EP. Subsequently, it was found that the interaction terms were negative and insignificant $(\beta=-0.119, t=0.773$, $p>0.005)$ and multi-collinearity $(\mathrm{VIF}=1.00)$ was not a problem. Thus, environmental concerns do not moderate the relationship between GSC and EP. Therefore, H12 was rejected. The findings show that the negative relationship between GSC and EP is weaker in an organization with high environmental concern. The moderating role of EC on GRCEP relationship was also examined. The result shows that the interaction term was positive and insignificant $(\beta=-0.142, t=0.838, p>0.005)$. Thus, environmental concerns do not moderate the GRC-EP relationship. Therefore, H13 was rejected. This also revealed that the integration of environmental concerns weakens the relationship between GRC and EP. Lastly, the moderating role of EC on ER-EP relationship was also investigated, and the result also provide the same evidence with the previous result where the interaction term was found to be negative and insignificant $t(\beta=-0.101, t=1.090, p>0.005)$. With this result, we conclude that environmental concern failed to moderate the ER-EP relationship, thus H14 was rejected. As such, the direct effect of ER-EP is weaker with the presence of environmental concern. The simple slope analyses of the moderating effects were provided in the appendix. Overall, Figure 2 provides details on the significance and path coefficients whereby Table 6 and Figures 3-6 offers details on the interaction effect of environmental concerns.

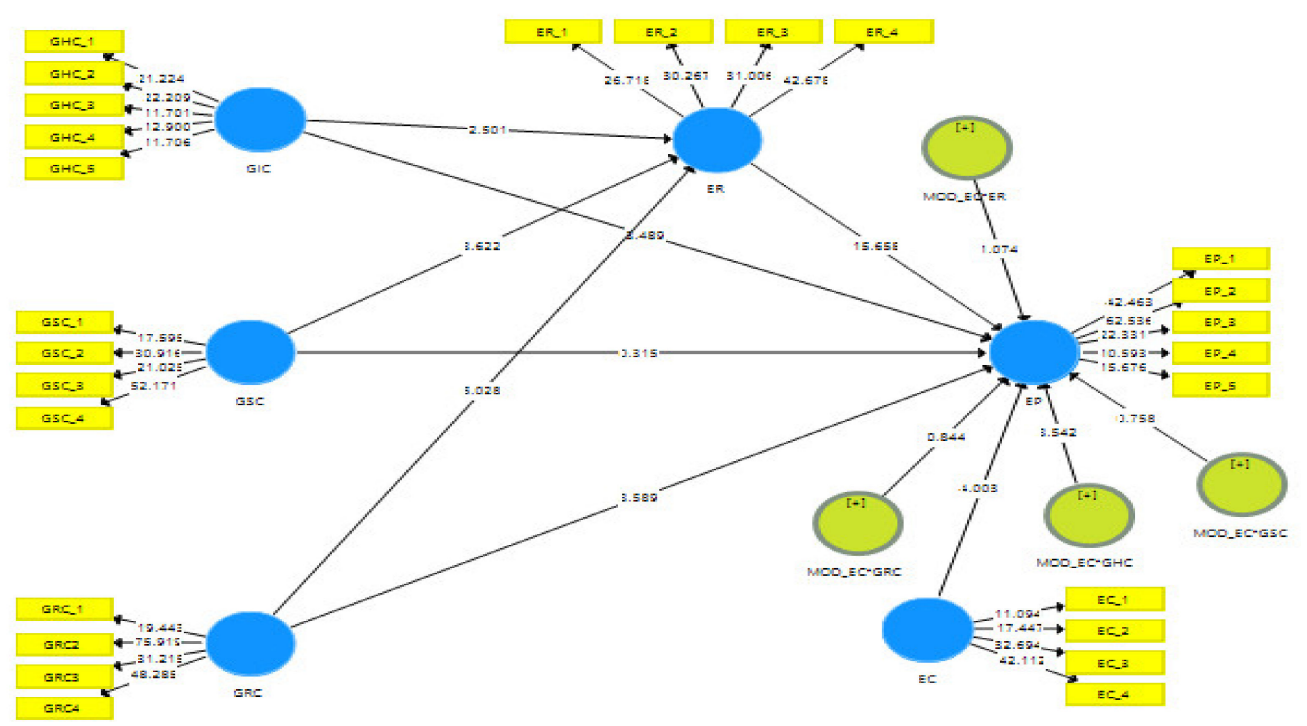

Figure 2. Structural Model.

Table 6. Moderation analysis.

\begin{tabular}{cccccc}
\hline Constructs & $\boldsymbol{\beta}$ & $\mathrm{SD}$ & $\boldsymbol{t}$-Value & $\boldsymbol{p}$-Value & Decision \\
\hline $\mathrm{GHC}^{*} \mathrm{EC} \rightarrow \mathrm{EP}$ & 0.100 & 0.028 & 3.542 & 0.000 & Supported \\
\hline $\mathrm{GSC}^{*} \mathrm{EC} \rightarrow \mathrm{EP}$ & -0.119 & 0.157 & 0.758 & 0.449 & Not supported \\
\hline $\mathrm{GRC}^{*} \mathrm{EC} \rightarrow \mathrm{EP}$ & 0.142 & 0.169 & 0.844 & 0.400 & Not supported \\
\hline $\mathrm{ER}^{*} \mathrm{EC} \rightarrow \mathrm{EP}$ & -0.101 & 0.094 & 1.074 & 0.284 & Not supported \\
\hline
\end{tabular}

Notes: GHC: means green human capital; GSC: means green structural capital; GRC: means green relational capital; EP: means environmental performance; ER: means environmental responsibility; $\beta$ : is the path coefficients: SD: means standard deviation. 


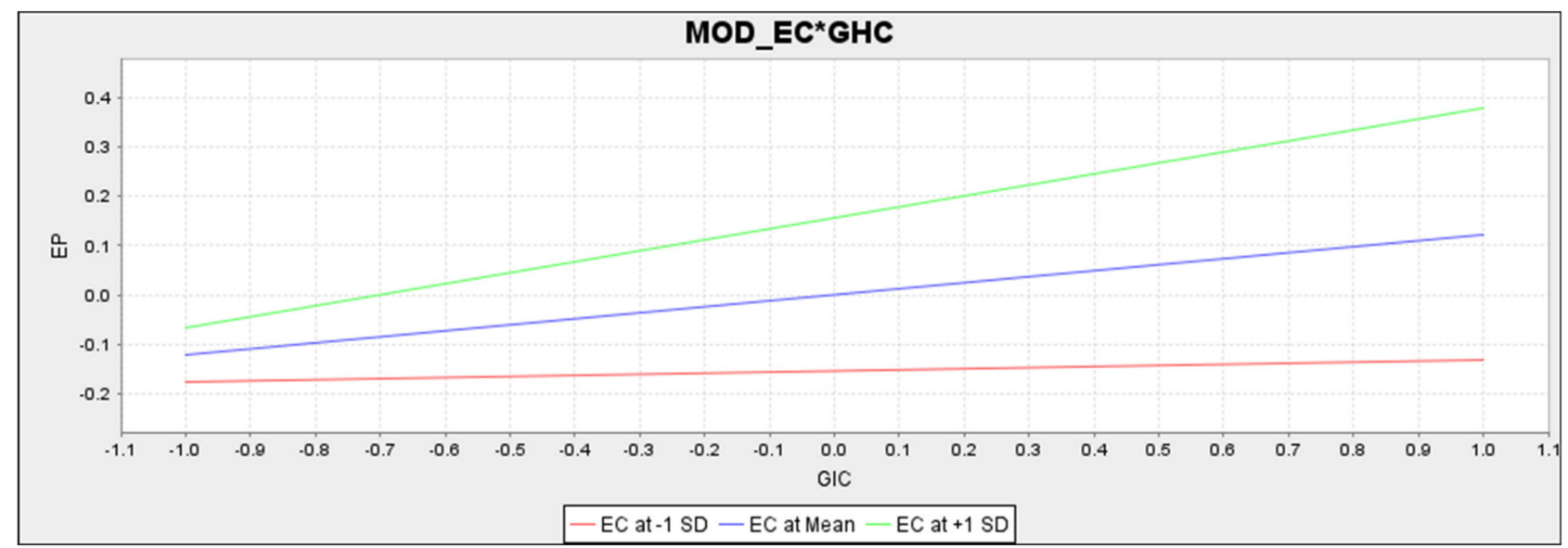

Figure 3. Interaction Effect of green human capital, environmental concern and environmental performance. Source: The authors.

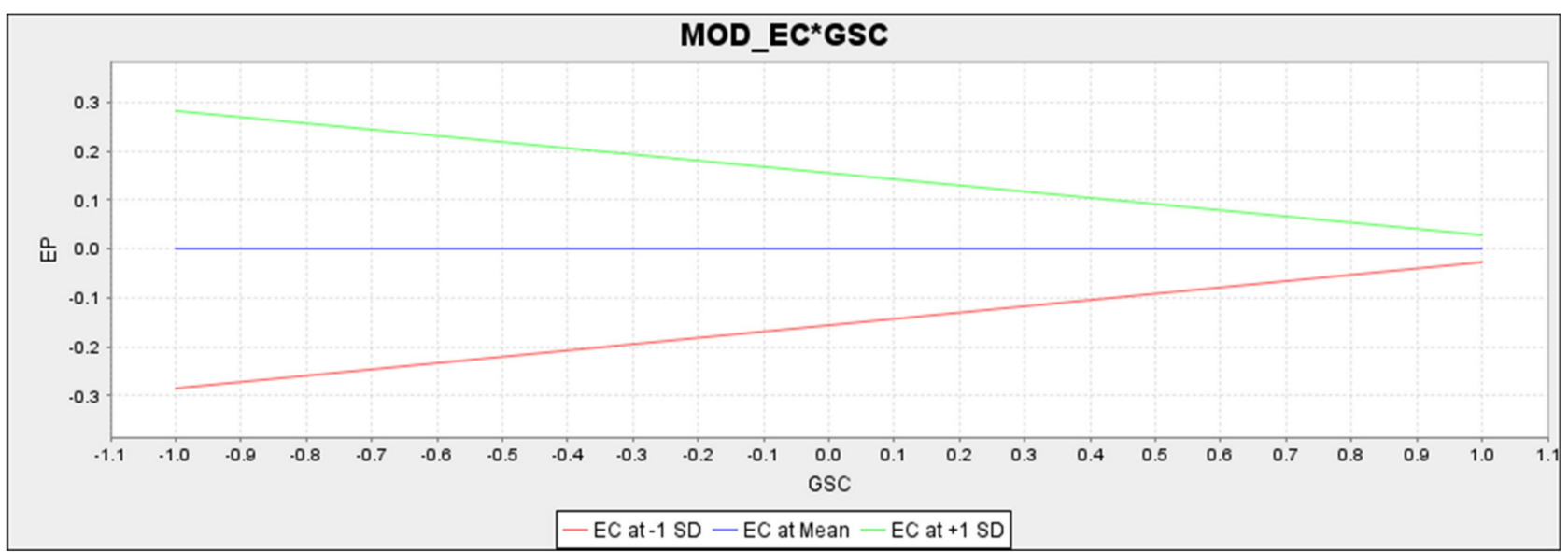

Figure 4. Interaction Effect of green structural capital, environmental concern and environmental performance. Source: The authors.

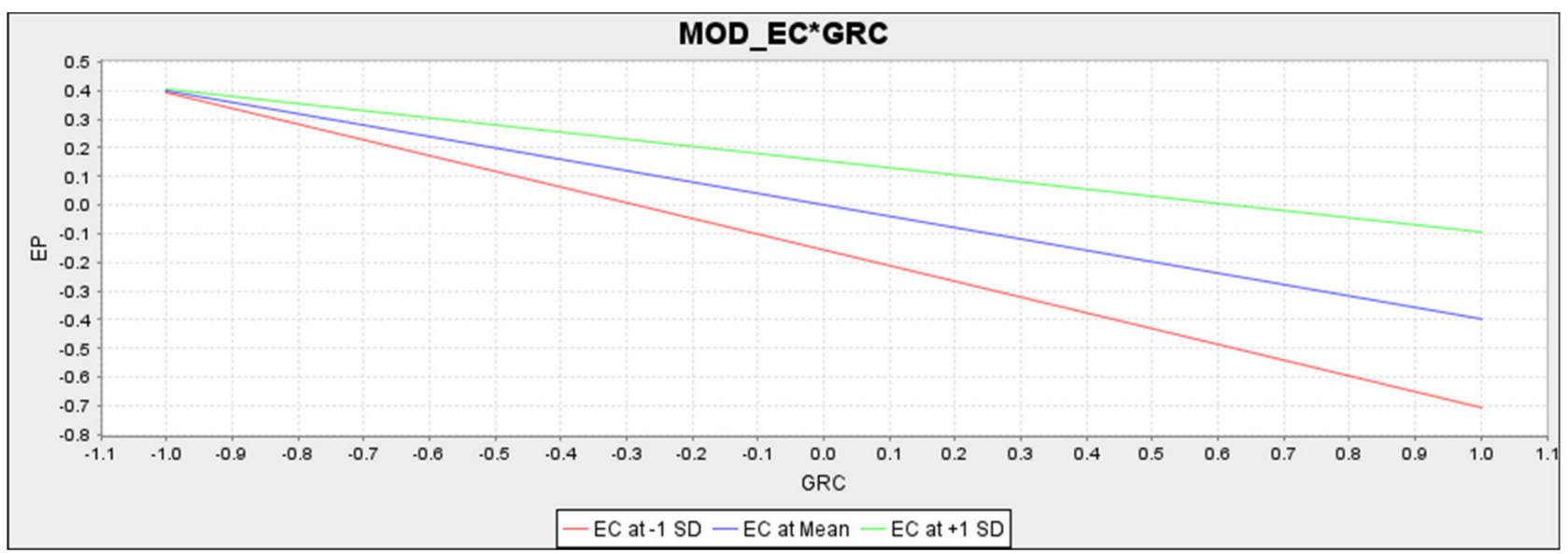

Figure 5. Interaction Effect of green relational capital, environmental concern and environmental performance. Source: The authors. 


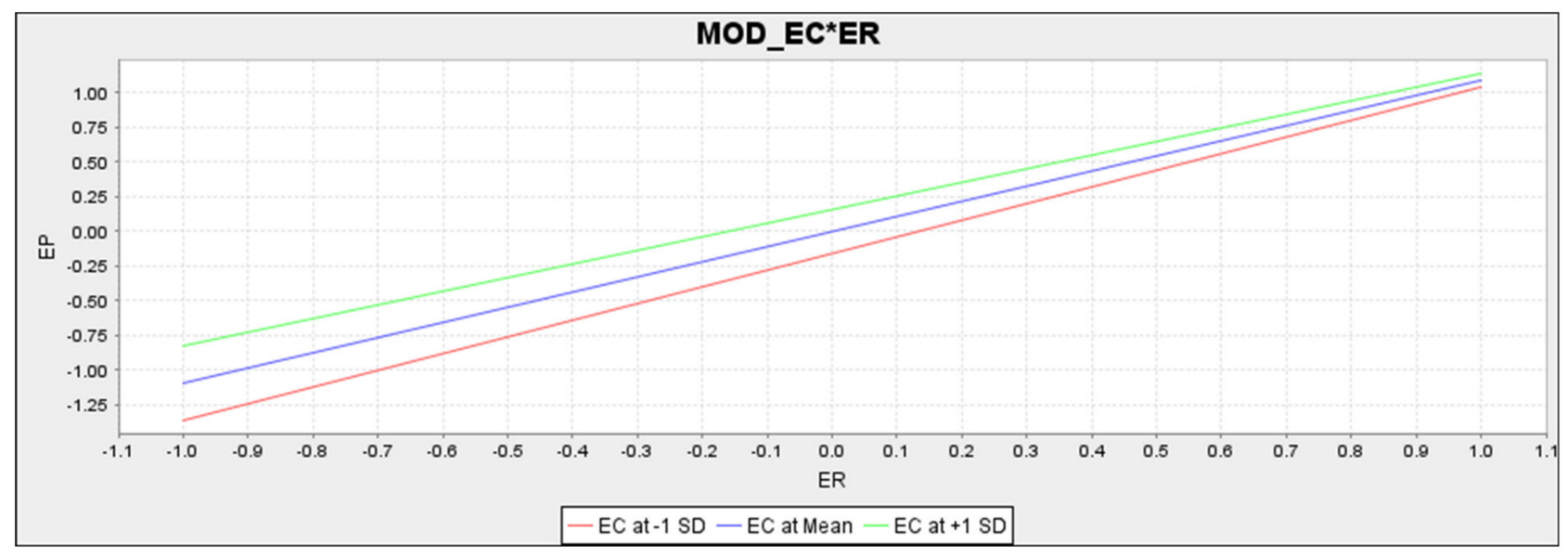

Figure 6. Interaction Effect of green relational capital, environmental concern and environmental performance. Source: The authors.

\section{Discussion of Findings}

The aim of the present study is to investigate the influence of green intellectual capital (e.g., green human capital, green structural capital and green relational capital) on environmental performance with the mediating role of environmental responsibility and the moderating role of environmental concern. This paper highlighted the importance of green intellectual capital for hotel organizations in Bahrain and UAE in order to progress competitively and enhance their environmental performance. The empirical findings show many important results in this study. First, on the direct relationship, green human capital was positively and significantly related to environmental performance. This result confirms the assertion of Huang and Kung [31] that green human capital encompasses environmental excellence and contribution to organizational performance.

Second, contrary to expectations, green structural capital was found to have a negative and insignificant effect on environmental performance. This result is fully supported by the findings of Yong et al. [3], who also found green structural capital does not have a significant relationship with green human resource management, and that of Chuang and Huang [92], who found green structural capital to insignificantly influence environmental performance. In addition, this finding was partly confirmed by the study of Delgado-Verde, Amores-Salvadó, Castro, and Navas-López [93], who concluded that green organizational capital was not explicitly linked to environmental product innovation but via the use of green social capital. A probable justification for this association is that environmental considerations might have been integrated into their recent management systems due to conformity with ISO 14,000 requirements. ISO 14,000 is a worldwide sequence of environmental management systems (EMS) principles that ensures that businesses handle their environmental obligations appropriately.

Third, the result of this study supports the expectations that green relational capital positively and significantly impacts environmental performance. This finding was also in tandem with the findings of Yong et al. [3], who also found green relational capital to positively influence green human resource management practices. Fourth, environmental responsibility was found to influence environmental performance positively and significantly. Our main effects demonstrated the significance of green intellectual capital (GIC) to the improvement of environmental responsibility and environmental performance of hotels. This result was contrary to Rehman et al. [94], who found green intellectual capital (e.g., green human capital, green intellectual capital, and green relations capital) not to be related to environmental performance. However, on the other hand, this result provides support to some prior studies $[7,92,95]$ who found also found a positive and significant relationship between green human capital and green relational capital and environmental performance. 
Furthermore, Seman et al. [96] also found a significant and positive relationship between green innovation and environmental performance. As well as El-Kassar and Singh [97], who found green innovation to enhance the competitive edge of an organization. As opined by Buysse and Verbeke [98], emphasizing environmental issues will devote more resources to green management practices. Hence, these findings indicate the relevance of developing green intellectual capital practices in the hospitality sector, specifically, the Hotelier organizations, which serves as an innovative strategic approach for the concerned organizations. Therefore, the present paper confirmed the significant influence of green intellectual capital on enhancing the environmental performance of organizations, particularly in the hotel sector.

Besides that, the present study evidenced the indirect effect of green intellectual capital on environmental performance through the mediating role of environmental responsibility. It was found that environmental responsibility mediates the relationship between green human capital and environmental performance. Second, the findings also reveal that the relationship between green structural capital and environmental performance is mediated by environmental responsibility. Lastly, environmental responsibility also mediates green relational capital and environmental performance. The other existing studies confirmed these findings [38] who also confirmed that environmental responsibility/consciousness positively mediates the relationship between green intellectual capital and corporate social performance. Furthermore, Krausa et al. [82] also found environmental strategy and innovation to mediate the relationship between corporate social responsibility and environmental performance. While Rötzel et al. [99] in their study, found a conflicting result that environmental strategy does play a mediating role in evaluating managerial performance.

Hence, this study indicates that green human capital and green relational capital can not only directly influence environmental performance positively but also via the intervening of environmental responsibility. In addition, it was verified in this study that green structural capital does not influence environmental performance directly but with the full mediation of environmental performance. Consequently, the standardized regression weight for the direct relationship between environmental responsibility and environmental performance was found to be significantly positive. Provided that all the indirect relationships between green intellectual capital and environmental performance were statistically significant, the mediating role of environmental responsibility was then ascertained. This suggests that the increase in green intellectual capital potentially results in higher environmental responsibility and subsequently enhances environmental performance.

Furthermore, the moderating role of environmental concern revealed that the positive relationship between green human capital and environmental performance is strongly moderated by environmental concern. This result was in line with the findings of Rehman et al. [94], who also found environmental strategy moderating the relationship between green innovation and environmental performance. Subsequently, it was also found that green structural capital and environmental performance relationship is not moderated by environmental concern, thereby weakening the direct positive relationship between green structural capital and environmental performance. This result was contrary to the findings of Chan, Yee, Dai, and Lim [100], who asserted that environmental dynamism moderates the relationship between green innovation and environmental performance. We further examined the moderating role of environmental concern on green relational capital and environmental performance relationship. The result also revealed that environmental concern does not moderate the relationship. Lastly, our result revealed that environmental concern does not strengthen the direct relationship between environmental responsibility and environmental performance. 


\section{Implications for Theory and Practice}

The findings of the current study offer novel contributions to theory and managerial practice. The current study has enriched the theoretical standpoint of intellectual capitalbased view theory outlining how an organization can obtain pro-environment performance through its intangible resources [101].

Notably, the study has addressed major gaps in the intellectual capital domain in its connection with environmental performance alongside intervening and interacting effects of environmental responsibility and environmental concerns, respectively. In particular, the study appears to be amongst the first attempts addressing the links between green intellectual capital and environmental performance. Accordingly, to the best of the authors' knowledge, the current study appears to be the first investigating the relationship mediation of environmental responsibility in the green intellectual capital and environmental performance association. Similarly, the current study appears to be the first to test the moderation of environmental concerns on the intellectual capital and environmental performance association. While responding to Umrani et al. [4] on environmental responsibility and concerns, the current study, particularly for environmental responsibility, has outlined its significance in harnessing pro-environment performance.

Contextually, the current study happens to be the first testing associations between green intellectual capital, environmental responsibility, and environmental concerns towards environmental performance in the hotel sector of Bahrain and UAE. The study has added noteworthy empirical evidence highlighting how green intellectual capital in the hospitality sector can lead towards pro-environment prospects. In addition, the promising statistical results educate on how managers should manage their green intellectual capital for green behaviors and outcomes.

Accordingly, the study also presents some important managerial implications. Since the study was conducted across 3 and 4-star hotels in Bahrain and UAE, the study highlights the need for management entities to consider prioritizing green intellectual capital. The findings suggest for the hotel sector that boosting environmental performance is coupled with the environmentally friendly intellectual capital and the extent of pro-environment responsibility and concern in employees. The investigated model of the study pioneers to guide the hotel sector in Bahrain and UAE to understand how green intellectual capital can open up prospects for harnessing pro-environment behaviors and outcomes. The study confirms the impact of intellectual resources in achieving sustainable organizational goals. Notably, keeping in view the growing trend of environmentally friendly outlook and performance in the hospitality sector $[4,66,102]$, the current study offers a novel strategy for hotels in Bahrain and UAE to work on green skills, abilities, and capabilities to make then environmentally responsible. Training interventions can be instrumental in enriching employees' skills, abilities, and capabilities in this regard. In addition, learning interventions followed by management support may help employees nourish environmental responsibility as well for enhanced environmental outcomes.

Furthermore, top management needs to look into providing opportunities for employees to practice green behaviors. Accordingly, managers should look into setting pro-environment goals and clasp them with organizational rewards. Typically, employees will be more encouraged to exercise environmental protection when their actions are connected with rewards $[59,103]$. Accordingly, collaboration with stakeholders may also turn fruitful whereby the study suggests that hotels partner with other hotels, suppliers to enhance environmental awareness and market information. This may also pave the way for knowledge sharing and skills exchange to boost environmental performance, reduce waste, and business efficiency. 


\section{Limitations and Scope for Future Research}

At first, the study was conducted on the 3 and 4-star hotels in Bahrain and UAE, hence limiting its generalizability. Bloom and Reenen [104] assert that management actions and how they make an impact differ from one sector to another. Similarly, it alters from one geographical setting to another. In light of this argument, there are likely chances of variation in the nexus between green intellectual capital, environmental responsibility, concern, and environmental performance. Future studies thus may consider validating the findings across different occupations, industries, and demographic settings. Accordingly, the study did not find much empirical support on the moderation of environmental concerns, thus encouraging future scholars to see how it interacts with diverse respondents. Accordingly, scholars are welcome to extend the model and test other potential predicting, interacting, and intervening variables to understand environmental performance. One suggestion would be to test green HRM $[4,102,105]$ towards the environmental performance followed by the mediation of green intellectual capital. This may also serve to respond and confirming to scholars outlining the limited intervening role of intellectual capital [106]. Equally, another interesting area for investigation will be testing psychological factors such as OCB [107] (Daily et al. 2009) and organizational pride [108] (Raza et al., 2020). Accordingly, the prediction of environmental performance may also be examined through testing with diverse theoretical understandings. This will provide an opportunity to assess different factors to help develop a better understanding of the construct.

Author Contributions: Formal analysis, U.A.; Investigation, U.A.; Methodology, S.M.; Project administration, S.M.M.S.; Resources, U.A., A.I.I. and S.M.; Writing-original draft Preparation, S.M.M.S. and U.A.; Writing-review and editing, A.I.I. All authors have duly contributed in the manuscript based on their skills and area of expertise. The authors have also read and agreed to the final version of the manuscript. All authors have read and agreed to the published version of the manuscript.

Funding: This research received no external funding.

Institutional Review Board Statement: Not applicable.

Informed Consent Statement: All the respondents were informed regarding the research intention, objectives and data confidentiality.

Data Availability Statement: All the data of the study are presented within the manuscript.

Conflicts of Interest: The authors declare no conflict of interest.

\section{References}

1. Saifulina, N.; Carballo-Penela, A. Promoting sustainable development at an organizational level: An analysis of the drivers of workplace environmentally friendly behaviour of employees. Sustain. Dev. 2017, 25, 299-310. [CrossRef]

2. Al-Hajri, S.A. Employee Retention in light of Green HRM practices through the Intervening role of Work Engagement. Ann. Contemp. Dev. Manag. HR 2020, 2, 10-19. [CrossRef]

3. Yong, J.Y.; Yusliza, M.Y.; Ramayah, T.; Fawehinmi, O. Nexus between green intellectual capital and green human resource management. J. Clean. Prod. 2019, 215, 364-374. [CrossRef]

4. Umrani, W.A.; Channa, N.A.; Yousaf, A.; Ahmed, U.; Pahi, M.H.; Ramayah, T. Greening the workforce to achieve environmental performance in hotel industry: A serial mediation model. J. Hosp. Tour. Manag. 2020, 44, 50-60. [CrossRef]

5. Yucedag, C.; Kaya, L.G.; Cetin, M. Identifying and assessing environmental awareness of hotel and restaurant employees' attitudes in the Amasra District of Bartin. Environ. Monit. Assess. 2018, 190, 1-8. [CrossRef] [PubMed]

6. Yusoff, Y.M.; Omar, M.K.; Zaman, M.D.K.; Samad, S. Do all elements of green intellectual capital contribute toward business sustainability? Evidence from the Malaysian context using the Partial Least Squares method. J. Clean. Prod. 2019, 234, 626-637. [CrossRef]

7. Chen, Y.S. The positive effect of green intellectual capital on competitive advantages of firms. J. Bus. Ethics 2008, 77, 271-286. [CrossRef]

8. Allameh, S.M. Antecedents and consequences of intellectual capital. J. Intellect. Cap. 2018, 19, 858-874. [CrossRef]

9. Kamukama, N.; Ahiauzu, A.; Ntayi, J.M. Competitive advantage: Mediator of intellectual capital and performance. J. Intellect. Cap. 2011, 12, 152-164. [CrossRef]

10. Phusavat, K.; Comepa, N.; Sitko-Lutek, A.; Ooi, K.B. Interrelationships between intellectual capital and performance. Ind. Manag. Data Syst. 2011, 111, 810-829. [CrossRef] 
11. ETA Board. 6 Best Countries to Visit in Persian Gulf. 2017. Available online: https:/ / etabroad.com/en/6-best-countries-to-visitin-persian-gulf/ (accessed on 19 June 2020).

12. World Tourism Forum. 2020. Available online: https://worldtourismforum.net/tourism-in-bahrain/ (accessed on 26 June 2020).

13. Nimri, R.; Patiar, A.; Kensbock, S. A green step forward: Eliciting consumers' purchasing decisions regarding green hotel accommodation in Australia. J. Hosp. Tour. Manag. 2017, 33, 43-50. [CrossRef]

14. Agostini, L.; Nosella, A.; Filippini, R. Does intellectual capital allow improving innovation performance? A quantitative analysis in the SME context. J. Intellect. Cap. 2017, 18, 400-418. [CrossRef]

15. Eisenhardt, K.M.; Schoonhoven, C.B. Resource-based view of strategic alliance formation: Strategic and social effects in entrepreneurial firms. Organ. Sci. 1996, 7, 136-150. [CrossRef]

16. Obeng, B.A.; Robson, P.; Haugh, H. Strategic entrepreneurship and small firm growth in Ghana. Int. Small Bus. J. 2017, 32, 501-524. [CrossRef]

17. Berezinets, I.; Garanina, T.; Ilina, Y. Intellectual capital of a board of directors and its elements: Introduction to the concepts. J. Intellect. Cap. 2016, 17, 632-653. [CrossRef]

18. Roos, G. Knowledge management, intellectual capital, structural holes, economic complexity and national prosperity. J. Intellect. Cap. 2017, 18, 745-770. [CrossRef]

19. Alcaniz, L.; Gomez-Bezares, F.; Roslender, R. Theoretical perspectives on intellectual capital: A backward look and a proposal for going forward. Account. Forum 2011, 35, 104-117. [CrossRef]

20. Ahmad, M.; Ahmed, N. Testing the relationship between intellectual capital and a firm's performance: An empirical investigation regarding financial industries of Pakistan. Int. J. Learn. Intellect. Cap. 2016, 13, 250-272. [CrossRef]

21. Verbano, C.; Crema, M. Linking technology innovation strategy, intellectual capital and technology innovation performance in manufacturing SMEs. Technol. Anal. Strateg. Manag. 2016, 28, 524-540. [CrossRef]

22. Bontis, N. Intellectual capital: An exploratory study that develops measures and models. Manag. Decis. 1998, 36, 63-76. [CrossRef]

23. Serenko, A.; Bontis, N. Meta-review of knowledge management and intellectual capital literature: Citation impact and research productivity rankings. Knowl. Process Manag. 2004, 11, 185-198. [CrossRef]

24. Marr, B.; Moustaghfir, K. Defining intellectual capital: a three-dimensional approach. Manag. Decis. 2005, 43, 1114-1128. [CrossRef]

25. Roos, G.; Roos, J. Measuring your company's intellectual performance. Long Range Plan. 1997, 30, 413-426. [CrossRef]

26. Bontis, N.; Keow, W.C.C.; Richardson, S. Intellectual capital and business performance in Malaysian industries. J. Intellect. Cap. 2000, 1, 85-100. [CrossRef]

27. Choong, K.K. Intellectual capital: Definitions, categorization and reporting models. J. Intellect. Cap. 2008, 9, 609-638. [CrossRef]

28. Liu, C.C. Developing green intellectual capital in companies by AHP. In 8th International Conference on Supply Chain Management and Information. 2010, pp. 1-5. Available online: https://ieeexplore.ieee.org/abstract/document/5681779/ (accessed on 22 June 2020).

29. Chen, Y.S. Green organizational identity: Sources and consequence. Manag. Decis. 2011, 49, 384-404. [CrossRef]

30. Singh, S.K.; Chen, J.; Del Giudice, M.; El-Kassar, A.N. Environmental ethics, environmental performance, and competitive advantage: Role of environmental training. Technol. Forecast. Soc. Chang. 2019, 146, 203-211. [CrossRef]

31. Huang, C.-L.; Kung, F.-H.H. Environmental consciousness and intellectual capital management: Evidence from Taiwan's manufacturing industry. Manag. Decis. 2011, 49, 1405-1425. [CrossRef]

32. Aboelmaged, M.; Hashem, G. Absorptive capacity and green innovation adoption in SMEs: The mediating effects of sustainable organisational capabilities. J. Clean. Prod. 2019, 220, 853-863. [CrossRef]

33. Erinos, N.R.; Yurniwati, Y. Green Intellectual Capital and Financial Performance of Corporate Manufacture in Indonesia. 2018. Available online: http:/ / piceeba.fe.unp.ac.id/index.php/index/index (accessed on 16 July 2020).

34. Wright, P.M.; McMahan, G.C.; McWilliams, A. Human resources and sustained competitive advantage: a resource-based perspective. Int. J. Hum. Resour. Manag. 1994, 5, 301-326. [CrossRef]

35. Subramaniam, M.; Youndt, M.A. The influence of intellectual capital on the types of innovative capabilities. Acad. Manag. J. 2005, 48, 450-463. [CrossRef]

36. Davidsson, P.; Honig, B. The role of social and human capital among nascent entrepreneurs. J. Bus. Ventur. 2003, 18, 301-331. [CrossRef]

37. Mention, A.L.; Bontis, N. Intellectual capital and performance within the banking sector of Luxembourg and Belgium. J. Intellect. Cap. 2013, 14, 286-309. [CrossRef]

38. Chang, C.H.; Chen, Y.S. The determinants of green intellectual capital. Manag. Decis. 2012, 50, 74-94. [CrossRef]

39. Yusliza, M.Y.; Yong, J.Y.; Tanveer, M.I.; Ramayah, T.; Faezah, J.N.; Muhammad, Z. A structural model of the impact of green intellectual capital on sustainable performance. J. Clean. Prod. 2020, 249, 119334. [CrossRef]

40. Jardon, C.M.; Dasilva, A. Intellectual capital and environmental concern in subsistence small businesses. Manag. Environ. Qual. Int. J. 2017, 28, 214-230. [CrossRef]

41. Widener, S.K. Human capital, pay structure, and the use of performance measures in bonus compensation. Manag. Account. Res. 2006, 17, 198-221. [CrossRef]

42. Florin, J.; Lubatkin, M.; Schulze, W. A social capital model of high-growth ventures. Acad. Manag. J. 2003, 46, 374-384. 
43. Lee, S.; Prabhu, V.V. Energy-aware feedback control for production scheduling and capacity control. Int. J. Prod. Res. 2015, 53, 7158-7170. [CrossRef]

44. Kuo, L.; Yu, H.C.; Chang, B.G. The signals of green governance on mitigation of climate change-evidence from Chinese firms. Int. J. Clim. Chang. Strateg. Manag. 2015, 7, 154-171. [CrossRef]

45. Yusoff, Y.M.; Ramayah, T.; Othman, N.Z. Why examining adoption factors, HR role and attitude towards using E-HRM is the start-off in determining the successfulness of green HRM. J. Adv. Manag. Sci. 2015, 3, 337-343. [CrossRef]

46. Firmansyah, A. Pengaruh green intellectual capital dan manajemen lingkungan organisasi terhadap green organizational identity dan dampaknya terhadap green competitive advantage. Substansi Sumber Artik. Akunt. Audit. Dan Keuang. Vokasi 2017, 1, 183-219.

47. Niesten, E.; Jolink, A.; de Sousa Jabbour, A.B.L.; Chappin, M.; Lozano, R. Sustainable collaboration: The impact of governance and institutions on sustainable performance. J. Clean. Prod. 2017, 155, 1-6. [CrossRef]

48. Doz, Y. Managing technological innovation in large complex firms: The contribution of human resource management. In Human Resource Management in International Firms; Palgrave Macmillan: London, UK, 1990; pp. 200-215.

49. Bonner, J.M.; Walker, O.C., Jr. Selecting influential business-to-business customers in new product development: Relational embeddedness and knowledge heterogeneity considerations. J. Prod. Innov. Manag. 2004, 21, 155-169. [CrossRef]

50. Walter, A. Relationship-specific factors influencing supplier involvement in customer new product development. J. Bus. Res. 2003, 56, 721-733. [CrossRef]

51. Dickel, P.; Hörisch, J.; Ritter, T. Networking for the environment: The impact of environmental orientation on start-ups' networking frequency and network size. J. Clean. Prod. 2018, 179, 308-316. [CrossRef]

52. Luthra, S.; Garg, D.; Haleem, A. The impacts of critical success factors for implementing green supply chain management towards sustainability: an empirical investigation of Indian automobile industry. J. Clean. Prod. 2016, 121, 142-158. [CrossRef]

53. Tonial, G.; Cassol, A.; Selig, P.M.; Giugliani, E. Intellectual capital management and sustainability activities in Brazilian organizations: A case study. In Intellectual Capital Management as a Driver of Sustainability; Springer: Cham, Switzerlands, 2019; pp. 119-138.

54. Aarnio-Linnanvuori, E. How do teachers perceive environmental responsibility? Environ. Educ. Res. 2019, 25, 46-61. [CrossRef]

55. Shvarts, E.A.; Pakhalov, A.M.; Knizhnikov, A.Y. Assessment of environmental responsibility of oil and gas companies in Russia: the rating method. J. Clean. Prod. 2016, 127, 143-151. [CrossRef]

56. Dilla, W.; Janvrin, D.; Perkins, J.; Raschke, R. Do environmental responsibility views influence investors' use of environmental performance and assurance information? Sustain. Account. Manag. Policy J. 2019, 10, 476-496. [CrossRef]

57. Middlemiss, L. Reframing individual responsibility for sustainable consumption: Lessons from environmental justice and ecological citizenship. Environ. Values 2010, 19, 147-167. [CrossRef]

58. Fahlquist, J.N. Moral responsibility for environmental problems-Individual or institutional? J. Agric. Environ. Ethics 2009, 22, 109-124. [CrossRef]

59. Saeed, B.B.; Afsar, B.; Hafeez, S.; Khan, I.; Tahir, M.; Afridi, M.A. Promoting employee's proenvironmental behavior through green human resource management practices. Corp. Soc. Responsib. Environ. Manag. 2019, 26, 424-438. [CrossRef]

60. Poduska, R.; Forbes, R.; Bober, M. The challenge of sustainable development. Columbia J. World Bus. 1992, 27, $286-291$.

61. Reilly, W.K. Environment, Inc. Bus. Horiz. 1992, 35, 9-11. [CrossRef]

62. Stanwick, P.A.; Stanwick, S.D. The relationship between corporate social performance, and organizational size, financial performance, and environmental performance: An empirical examination. J. Bus. Ethics 1998, 17, 195-204. [CrossRef]

63. Turker, D. How corporate social responsibility influences organizational commitment. J. Bus. Ethics 2009, 89, 189-204. [CrossRef]

64. Yen, C.H.; Chen, C.Y.; Teng, H.Y. Perceptions of environmental management and employee job attitudes in hotel firms. J. Hum. Resour. Hosp. Tour. 2013, 12, 155-174. [CrossRef]

65. Han, H.; Yu, J.; Kim, W. Environmental corporate social responsibility and the strategy to boost the airline's image and customer loyalty intentions. J. Travel Tour. Mark. 2019, 36, 371-383. [CrossRef]

66. Kim, Y.J.; Kim, W.G.; Choi, H.M.; Phetvaroon, K. The effect of green human resource management on hotel employees' eco-friendly behavior and environmental performance. Int. J. Hosp. Manag. 2019, 76, 83-93. [CrossRef]

67. Guerci, M.; Longoni, A.; Luzzini, D. Translating stakeholder pressures into environmental performance the mediating role of green HRM practices. Int. J. Hum. Resour. Manag. 2016, 27, 262-289. [CrossRef]

68. Amran, A.; Ooi, S.K.; Nejati, M.; Zulkafli, A.H.; Lim, B.A. Relationship of firm attributes, ownership structure and business network on climate change efforts: evidence from Malaysia. Int. J. Sustain. Dev. World Ecol. 2012, 19, 406-414. [CrossRef]

69. Tzafrir, S.S. The relationship between trust, HRM practices and firm performance. Int. J. Hum. Resour. Manag. 2005, 16, 1600-1622. [CrossRef]

70. Paillé, P.; Chen, Y.; Boiral, O.; Jin, J. The impact of human resource management on environmental performance: An employeelevel study. J. Bus. Ethics 2014, 121, 451-466. [CrossRef]

71. Melnyk, S.A.; Sroufe, R.P.; Calantone, R. Assessing the impact of environmental management systems on corporate and environmental performance. J. Oper. Manag. 2003, 21, 329-351. [CrossRef]

72. Turker, D. Measuring corporate social responsibility: A scale development study. J. Bus. Ethics 2009, 85, 411-427. [CrossRef]

73. Malik, M.I.; Nawaz Mir, F.; Hussain, S.; Hyder, S.; Anwar, A.; Khan, Z.U. Contradictory results on environmental concern while re-visiting green purchase awareness and behavior. Asia Pac. J. Innov. Entrep. 2019, 13, 17-28. [CrossRef] 
74. $\quad$ Ringle, C.M.; Wende, S.; Becker, J.M. SmartPLS 3; SmartPLS GmbH: Boenningstedt, Germany, 2015.

75. Wong, K.K.-K. Partial least squares structural equation modeling (PLS-SEM) techniques using Smart PLS. Mark. Bull. 2013, 24, $1-32$.

76. Ringle, C.M.; Sarstedt, M.; Mitchell, R.; Gudergan, S.P. Partial least squares structural equation modeling in HRM research. Int. J. Hum. Resour. Manag. 2018, 1, 1-27. [CrossRef]

77. Preacher, K.J.; Hayes, A.F. Asymptotic and resampling strategies for assessing and comparing indirect effects in multiple mediator models. Behav. Res. Methods 2008, 40, 879-891. [CrossRef] [PubMed]

78. Hayes, A.F. Beyond Baron and Kenny: Statistical mediation analysis in the new millennium". Commun. Monogr. 2009, 76, 408-420. [CrossRef]

79. Hair, J.F.; Hult, G.T.M.; Ringle, C.M.; Sarstedt, M. A Primer on Partial Least Squares Structural Equation Modeling, 2nd ed.; SAGE Publications: Thousand Oaks, CA, USA, 2014.

80. Yong, J.Y.; Yusliza, M.Y.; Ramayah, T.; Chiappetta Jabbour, C.J.; Sehnem, S.; Mani, V. Pathways towards sustainability in manufacturing organizations: Empirical evidence on the role of green human resource management. Bus. Strategy Environ. 2020, 29, 212-228. [CrossRef]

81. Podsakoff, P.M.; MacKenzie, S.B.; Lee, J.Y. Common method biases in behavioral research: a critical review of the literature and recommended remedies. J. Appl. Psychol. 2003, 88, 879-903. [CrossRef]

82. Krausa, S.; Rehman, S.U.; Garcíac, F.J.S. Corporate social responsibility and environmental performance: The mediating role of environmental strategy and green innovation. Technol. Forecast. Soc. Chang. 2020, 160, 120262. [CrossRef]

83. Mahto, R.V.; Khanin, D. Satisfaction with past financial performance, risk taking, and future performance expectations in the family business. J Small Bus. Manag. 2015, 53, 801-818. [CrossRef]

84. Hair, J.F., Jr.; Sarstedt, M.; Ringle, C.M.; Gudergan, S.P. Advanced Issues in Partial Least Squares Structural Equation Modeling; Sage Publications: Thousand Oaks, CA, USA, 2017.

85. Sarstedt, M.; Ringle, C.M.; Henseler, J.; Hair, J.F. On the emancipation of PLS-SEM: A commentary on Rigdon (2012). Long Range Plan. 2014, 47, 154-160. [CrossRef]

86. Falk, R.F.; Miller, N.B. A Primer for Soft Modeling; University of Akron Press: Akron, OH, USA, 1992.

87. Geisser, S. A predictive approach to the random effect model. Biometrika 1974, 61, 101-107. [CrossRef]

88. Stone, M. Cross-validatory choice and assessment of statistical predictions. J. R. Stat. Soc. Ser. B 1974, 36, 111-113. [CrossRef]

89. Chin, W.W. Commentary: Issues and opinion on structural equation modeling. MIS Q. 1998, 22, vii-xvi.

90. Cohen, L.; Manion, L.; Morrison, K. Research Methods in Education; Routledge: Oxfordshire, UK, 2013.

91. Henseler, J.; Ringle, C.M.; Sinkovics, R.R. The Use of Partial Least Squares Path Modeling in International Marketing New Challenges to International Marketing; Emerald Group Publishing Limited: Bingley, UK, 2013; Volume 20, pp. 277-319.

92. Chuang, S.-P.; Huang, S.-J. The Effect of Environmental Corporate Social Responsibility on Environmental Performance and Business Competitiveness: The Mediation of Green Information Technology Capital. J. Bus. Ethics 2018, 150, 991-1009. [CrossRef]

93. Delgado-Verde, M.; Amores-Salvadó, J.; Castro, G.M.; Navas-López, J.E. Green intellectual capital and environmental product innovation: The mediating role of green social capital. Knowl. Manag. Res. Pr. 2014, 12, 1-15.

94. Rehman, S.U.; Kraus, S. Shah, S.A.; Khanin, D.; Mahto, R.V. Analyzing the relationship between green innovation and environmental performance in large manufacturing firms. Technol. Forecast. Soc. Chang. 2021, 163, 120481. [CrossRef]

95. Van den Berg, U.; Labuschagne, J.-P.; Van den Berg, H. The effects of greening the supplier and innovation on environmental performance and competitive advantage. J. Transp. Supply Chain Manag. 2013, 7, 1-7. [CrossRef]

96. Seman, N.A.A.; Govindan, K.; Mardani, A.; Zakuan, N.; Saman, M.Z.M.; Hooker, R.E. The mediating effect of green innovation on the relationship between green supply chain management and environmental performance. J. Clean. Prod. 2019, 229, 115-127. [CrossRef]

97. El-Kassar, A.-N.; Singh, S.K. Green innovation and organizational performance: the influence of big data and the moderating role of management commitment and HR practices. Technol. Soc. Chang. 2019, 144, 483-498. [CrossRef]

98. Buysse, K.; Verbeke, A. Proactive environmental strategies: A stakeholder management perspective. Strateg. Manag. J. 2003, 24, 453-470. [CrossRef]

99. Rötzel, P.G.; Stehle, A.; Pedell, B.; Hummel, K. Integrating environmental management control systems to translate environmental strategy into managerial performance. J. Acc. Organ. Chang. 2019, 15, 626-653. [CrossRef]

100. Chan, H.K.; Yee, R.W.; Dai, J.; Lim, M.K. The moderating effect of environmental dynamism on green product innovation and performance. Int. J. Prod. Econ. 2016, 181, 384-391. [CrossRef]

101. Youndt, M.A.; Snell, S.A. Human resource configurations, intellectual capital, and organizational performance. J. Manag. Issues 2004, 16, 337-360.

102. Pham, N.T.; Thanh, T.V.; Tučková, Z.; Thuy, V.T.N. The role of green human resource management in driving hotel's environmental performance: Interaction and mediation analysis. Int. J. Hosp. Manag. 2020, 88, 102392. [CrossRef]

103. Ansari, N.Y.; Farrukh, M.; Raza, A. Green human resource management and employees pro-environmental behaviours: Examining the underlying mechanism. Corp. Soc. Responsib. Environ. Manag. 2021, 28, 229-238. [CrossRef]

104. Bloom, N.; Van Reenen, J. Why do management practices differ across firms and countries? J. Econ. Perspect. 2010, $24,203-224$. [CrossRef] 
105. Benevene, P.; Buonomo, I. Green human resource management: An evidence-based systematic literature review. Sustainability 2020, 12, 5974. [CrossRef]

106. Jain, P.; Vyas, V.; Roy, A. Exploring the mediating role of intellectual capital and competitive advantage on the relation between CSR and financial performance in SMEs. Soc. Responsib. J. 2017, 13, 1-23. [CrossRef]

107. Daily, B.F.; Bishop, J.W.; Govindarajulu, N. A conceptual model for organizational citizenship behavior directed toward the environment. Bus. Soc. 2009, 48, 243-256. [CrossRef]

108. Raza, A.; Farrukh, M.; Iqbal, M.K.; Farhan, M.; Wu, Y. Corporate social responsibility and employees' voluntary pro-environmental behavior: The role of organizational pride and employee engagement. Corp. Soc. Responsib. Environ. Manag. 2021, 28, 1104-1116. [CrossRef] 